Asian J. Med. Biol. Res. 2017, 3 (1), 66-71; doi: 10.3329/ajmbr.v3i1.32038

\author{
Asian Journal of \\ Medical and Biological Research \\ ISSN 2411-4472 (Print) 2412-5571 (Online) \\ www.ebupress.com/journal/ajmbr
}

\title{
Article \\ Breeding for the improvement of indigenous chickens in Bangladesh: performance of second generation
}

\author{
Shakila Faruque $^{1}$, A.K.F.H. Bhuiyan ${ }^{2}$, Md. Yousuf Ali $^{3 *}$, M.S.K Sarker ${ }^{1}$ and Ziaul Faruque Joy ${ }^{4}$ \\ ${ }^{1}$ Poultry Production Research Division, Bangladesh Livestock Research Institute, Savar, Dhaka-1341, \\ Bangladesh \\ ${ }^{2}$ Department of Animal Breeding and Genetics, Bangladesh Agricultural University, Mymensingh-2202, \\ Bangladesh \\ ${ }^{3}$ Bangladesh Livestock Research Institute, Regional Station, Baghabari, Shahjadpur, Sirajgonj- 6770, \\ Bangladesh \\ ${ }^{4}$ Department of Genetic Engineering and Biotechnology, Shahjalal University of Science and Technology, \\ Sylhet-3114, Bangladesh
}

*Corresponding author: Md. Yousuf Ali, Bangladesh Livestock Research Institute, Regional Station, Baghabari, Shahjadpur, Sirajgonj, Bangladesh. E-mail: 113yousuf.bau@gmail.com, myousuf@blri.gov.bd

Received: 28 February 2017/Accepted: 20 March 2017/ Published: 30 March 2017

\begin{abstract}
The improvement of productivity of indigenous chicken is a long desire in the country. Present research is a part of the long-term selection program being undertaken to evaluate the carcass characteristics and expected response to selection of second generation $\left(\mathrm{G}_{2}\right)$ of indigenous chicken under intensive management in Bangladesh. A total of 1643-day-old chicks comprising of 3 types of chicken namely Naked Neck (NN), Hilly (H) and Non-descript Desi (ND) were hatched in a two batches for this study. In second generation $\left(\mathrm{G}_{2}\right)$, selection was practiced at 3 (three) stages of birds life, firstly and secondly at 8 and at 16 weeks of age, selection was performed on the basis of breeding value for 8 and 16 week body weight. Thirdly, at 40 -week of age, on the basis of an index comprising the parameters of age at sexual maturity (ASM), body weight (BW), egg production (EP) and egg weight (EW). Improvement target of egg weight was to increase by $1 \mathrm{~g}$ and improvement target of egg production rate was to increase by $2 \%$ per generation. The main target was the mean body weight in $\mathrm{H}, \mathrm{ND}$ and $\mathrm{NN}$ chicken has to be gone up from the initial eight-week body weight of 375,342 and $331 \mathrm{~g}$ to $500 \mathrm{~g}$ at eight weeks of age. At 8, 10 and 12 weeks of age, six birds from each genotype were slaughtered to analyze the meat yield traits. Slaughter data were analyzed in a 3 (genotype) $\times 3$ (slaughter age) factorial arrangement in CRD by General Linear Model (GLM) Univariate Procedure in SPSS Computer Program. Genotype and slaughter age had significant effect $(\mathrm{p}<0.001)$ on dressing percentage. Body weight at 8 weeks of age was expected to improve by 51.21 vs. $24.03 ; 37.74$ vs. 15.47 and 26.26 vs. $9.65 \mathrm{~g}$; respectively for $\mathrm{ND}, \mathrm{H}$ and $\mathrm{NN}$ males and females. In terms of body weight $\mathrm{H}$ genotype was superior and NN genotype was for dressing percentage. As a result of selection; EP, BW increased and ASM reduced in second generation than that of the foundation stock.
\end{abstract}

Keywords: indigenous chicken; generation; selective breeding; breeding value; performance

\section{Introduction}

The improvement of productivity of indigenous chicken is a long desire in the country. Indigenous chickens of Bangladesh are categorized as Non-descriptive Deshi (ND), Naked Neck (NN), Hilly (H), Aseel (AS) and Jungle fowl (Bhuiyan et al., 2005) in respect of the morphological variations as well as production performances. Bangladesh Livestock Research Institute (BLRI) since its inception did initiate programs for the conservation and development of indigenous chicken through several poultry development projects. As a part of 
selection and improvement of indigenous chicken, this work in the form of a Ph.D. research was being planned. It is a long-term vision. As a first step, foundation stock was established utilizing the existing stock of Bangladesh Livestock Research Institute (BLRI) as well as by incorporating variation through screening of males/females/eggs from a wider indigenous chicken gene pool of Bangladesh. Response observed in most of the selection experiments with egg number as a selection criterion suggested a negative genetic correlation between egg number and egg weight (Hazary et al., 1990). Mature body weight is closely related to initial egg weight, with heavier pullets producing heavier eggs (Prasad, 2000). Though early maturity and high rate of production are desirable goals, the gain in response may be at the expense of persistency if long enough records are not included in the selection. However, the present study was undertaken to evaluate the performance and expected response to selection of second generation $\left(G_{2}\right)$.

\section{Materials and Methods}

\subsection{Production of second generation $\left(G_{2}\right)$}

The study was conducted at Bangladesh Livestock Research Institute, under Poultry Production Research Division, Savar, Dhaka, Bangladesh. A total of 1643 progenies (ND=926, $\mathrm{H}=383$ and $\mathrm{NN}=334$ ) were hatched in a two batches for second generation $\left(\mathrm{G}_{2}\right)$. Day-old chicks collected from the hatchery were weighed and leg banded individually.

\subsection{Rearing and data collection of second generation $\left(\mathbf{G}_{2}\right)$}

All the chicks of three genotypes were transferred into the brooder, which were cleaned and disinfected earlier and $5 \%$ glucose solution was supplied for the first three days. One-week later leg bands were removed and wing bands were provided all the experimental birds. Debeaking was performed after 10-12 days of age. Concentrate mixtures that contain 20.06\% Crude Protein \& $2908 \mathrm{Kcal}$ ME/kg DM; 18.13\% Crude Protein \& 2904 Kcal $\mathrm{ME} / \mathrm{kg}$ DM and $16.33 \%$ Crude Protein \& $2845 \mathrm{Kcal}$ ME/kg DM were provided twice daily in the morning and evening during brooding, growing and laying period, respectively. Cool clean drinking water was supplied all the times. Water also was provided ad libitum twice daily in the morning and evening. Feeder and drinker were cleaned twice in a week. Refusals of the feed were measured everyday in the morning. All chicks were vaccinated as per schedule given by veterinarian. All productive and reproductive records are being kept.

\subsection{Selection and mating plan of second generation $\left(\mathbf{G}_{2}\right)$}

The selection objectives of the study were to improve the egg production, egg weight and / or growth rate of indigenous chicken depending on the genotype of birds. Improvement target of egg weight is to increase by $1 \mathrm{~g}$ and improvement target of egg production rate is to increase by $2 \%$ per generation. The main target was the mean body weight in ND, H, NN chickens have to be gone up from the initial eight-week body weight of 342, $375,331 \mathrm{~g}$ on an average $349 \mathrm{~g}$ to $500 \mathrm{~g}$ at 8 week of age after 3 generations of selective breeding. In second generation $\left(\mathrm{G}_{2}\right)$, selection was practiced at 3 (three) stages of birds life, firstly and secondly, at 8 and at 16 weeks of age, selection was performed on the basis of breeding value for 8 and 16 week body weight. At 8 weeks of age, a total of 460 females $(\mathrm{ND}=230, \mathrm{H}=115$ and $\mathrm{NN}=115)$ and 175 males $(\mathrm{ND}=85, \mathrm{H}=45$ and $\mathrm{NN}=$ 45) were selected according to breeding value on the basis of 8 week's body weight. At 16 weeks of age, a total of 400 females $(\mathrm{ND}=200, \mathrm{H}=100$ and $\mathrm{NN}=100)$ and 80 males $(\mathrm{ND}=40, \mathrm{H}=20$ and $\mathrm{NN}=20)$ were selected according to breeding value on the basis of 16 week's body weight. Thirdly, at 40-week of age, selection was done using multi trait index selection and independent culling level. The selection Index was computed by the following equation:

$$
\text { Selection Index }(I)=b_{1} x_{1}+b_{2} x_{2}+\ldots \ldots \ldots \ldots+b_{n} x_{n}
$$

Where, $\mathrm{x}_{1}, \mathrm{x}_{2}, \ldots \ldots . \mathrm{x}_{\mathrm{n}}$ represent the phenotypic value for the trait

$b_{1}, b_{2}, \ldots \ldots . b_{n}$ denote the relative weight given to each of the trait

The total score was obtained from above calculation is a selection index. The individual with the higher total score was selected for breeding purposes. Both index selection and independent culling levels were used to select chicken. Culling level used was as follows:

$\begin{array}{lll} & \text { Trait } & \text { Culling level } \\ \text { ASM } & & \mathrm{X} \leq \mathrm{AV}+2 \mathrm{SD} \\ \text { BW } & \mathrm{AV}-2 \mathrm{SD} \leq \mathrm{X} \leq \mathrm{AV}+2 \mathrm{SD} \\ \text { EW } & \mathrm{AV}-\mathrm{SD} \leq \mathrm{X} \leq \mathrm{AV}+\mathrm{SD} \\ \text { EP } & \mathrm{AV} \leq \mathrm{X} \\ \text { Index } & \mathrm{AV} \leq \mathrm{X}\end{array}$


A total of 37 males $(\mathrm{ND}=17, \mathrm{H}=10$ and $\mathrm{NN}=10)$ and 185 females $(\mathrm{ND}=85, \mathrm{H}=50$ and $\mathrm{NN}=50)$ were selected comprising the parameters of Age at first egg (days), Body weight (g) at Egg production percentage (168-280 days), 40 weeks of age and Egg Weight (g) at 38 - 40 weeks of age

A total of 20 males $(\mathrm{ND}=10, \mathrm{H}=5$ and $\mathrm{NN}=5$ ) and 40 female birds $(\mathrm{ND}=20, \mathrm{H}=10$ and $\mathrm{NN}=10$ ) were kept as spare birds. An assortative mating design was followed to keep inbreeding as low as possible.

\subsection{Breeding design and experimental chicken}

\begin{tabular}{|c|c|c|c|c|c|c|c|}
\hline \multirow{2}{*}{ 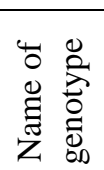 } & \multirow[b]{2}{*}{$\stackrel{x}{\vdots}$} & \multirow{2}{*}{ 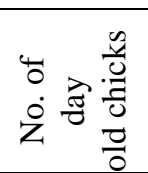 } & \multicolumn{2}{|c|}{ No. of growing chicks } & \multirow{2}{*}{$\begin{array}{ll}\text { No. } & \text { of } \\
\text { adult } & \\
\text { birds } & \end{array}$} & \multicolumn{2}{|c|}{$\begin{array}{l}\text { No. of selected bird } \\
\text { at } 40 \text { wks of age }\end{array}$} \\
\hline & & & 8 wks & 16 wks. & & Selected & Spare \\
\hline \multirow[t]{2}{*}{ ND } & Male & 926 & 85 & 40 & 40 & 17 & 10 \\
\hline & Female & & 230 & 200 & 200 & 85 & 20 \\
\hline \multirow[t]{2}{*}{$\mathrm{H}$} & Male & 383 & 45 & 20 & 20 & 10 & 5 \\
\hline & Female & & 115 & 100 & 100 & 50 & 10 \\
\hline \multirow[t]{2}{*}{$\mathrm{NN}$} & Male & 334 & 45 & 20 & 20 & 10 & 5 \\
\hline & Female & & 115 & 100 & 100 & 50 & 10 \\
\hline
\end{tabular}

2.5. AI and collection of hatching eggs to produce third generation $\left(G_{3}\right)$

Selected males and females were mated using artificial insemination. Artificial Insemination was practiced twice in a week. Hatching eggs were collected up to 10 days. Male birds were collected from different parts of Bangladesh to introduce new variability. Two batches were required to produce third generation $\left(\mathrm{G}_{3}\right)$.

\subsection{Data recording}

All productive and reproductive parameters were recorded for second generation $\left(G_{2}\right)$. Records were kept on day-old weight (g), fortnightly individual body weight up to 8 weeks, monthly weight up to 20 weeks, daily egg production, and egg weight at 38-40 weeks of age, temperature and humidity, growth rate, feed intake and feed conversion ratio (FCR). Feed conversion ratio (FCR) was recorded for the whole period as total feed intake $(\mathrm{kg})$ per $\mathrm{kg}$ weight gain. Temperature and humidity were recorded four times a day; $(06: 00 \mathrm{~h}, 12: 00 \mathrm{~h}, 18: 00 \mathrm{~h}$ and 24:00h).

\subsection{Slaughtering and carcass characteristics data}

At 8,10 and 12 weeks of age, six males of each genotype were slaughtered to analyze the meat yield traits. All chickens were kept off feed overnight before slaughtering but drinking water was provided ad libitum. Birds were slaughtered following 'halal' method (Singh et al., 2003) by severing the jugular vein allowed to bleed completely and then plucked and weighed to determine blood and feather losses (Kotula et al. 1960; Pandey and Shyamsunder, 1990). Pre-slaughter live weight, blood loss weight, eviscerated weight, breast meat weight, thigh plus drumstick weight etc. were recorded. All weight related to carcass characteristics were expressed as the percentage of live weight. Carcasses were dissected according to Singh et al. (2003) except that birds were not scalded.

\subsection{Statistical analysis}

The treatments were arranged in a 3 (genotype) $\times 3$ (slaughter age) factorial experiment. The data were analyzed by factorial arrangement in a CRD by General linear Model (GLM) Univariate Procedure in SPSS Computer Program. The following general linear statistical models were used to analyze the different parameters:

i) $Y_{i j}=\boldsymbol{\mu}+\mathbf{g}_{\mathbf{i}}+\mathbf{e}_{\mathrm{ij}}$, where, $Y_{\mathrm{ij}}$ is the dependent variable of the experiment; $\mu$ is the overall mean; $g_{\mathrm{i}}$ is the effect of $i$ th genotype ( $\mathrm{i}=1-3)$; $\mathrm{e}_{\mathrm{ij}}$ is the error term specific to each record.

ii) $\mathbf{Y}_{\mathrm{ij}}=\boldsymbol{\mu}+\mathbf{s}_{\mathbf{i}}++\mathbf{e}_{\mathrm{ij}}$, where, $\mathrm{Y}_{\mathrm{ij}}$ is the dependent variable of the experiment; $\mu$ is the overall mean; $\mathrm{s}_{\mathrm{i}}$ is the effect of $\mathrm{i}$ th slaughter age $(\mathrm{i}=1-3)$; $\mathrm{e}_{\mathrm{ij}}$ is the error term specific to each record.

\subsection{Prediction of expected selection response}

Expected selection response in three types of indigenous chicken for body weight at 8 weeks was estimated using the following equation (Falconer, 1981).

i) $\mathrm{R}=\mathrm{h}^{2} \times \mathrm{S}$ 
Where,

$\mathrm{R}=$ Expected response in mass selection

$\mathrm{h}^{2}=$ heritability, $\mathrm{h}^{2}$ for BW at 8 weeks of age

$\mathrm{S}=$ Selection differential

\section{Results and Discussion}

\subsection{Carcass characteristics}

Dressing percentage $(p<0.001)$ and live weight $(p<0.05)$ was affected by genotype (Table 1$)$. Significantly $(\mathrm{P}<0.001)$ higher dressing percentage was found in NN (67.29) genotype than that of ND (66.92) and H (65.4) genotypes. Similar result was found in NN (64.58) genotype than that of ND (60.26) and H (61.70) genotypes (Faruque et al., 2011). Iqbal et al. (2009) found the average live weight $1.72 \pm 0.04 \mathrm{~kg}$ and $1.25 \pm 0.02 \mathrm{~kg}$ for cock and hen respectively, which differed significantly $(\mathrm{p}<0.01)$ between the two sexes. They also reported that dressing percentage of $70.11 \pm 0.66$ for cock and $63.80 \pm 1.59$ for hen were significantly different $(p<0.01)$. There was significant $(\mathrm{P}<0.001)$ difference in live weight and dressing percentage between ages at slaughter (Table 2$)$.

\subsection{Selection differential, selection intensity and expected response to selection}

Selection differential at 8 weeks of age for ND, $\mathrm{H}$ and $\mathrm{NN}$ males were $102.63,77.20$ and $54.94 \mathrm{~g}$ respectively (Table 3). The corresponding values for females were 48.18, 31.65 and $20.19 \mathrm{~g}$. The intensity of selection for males at 8 weeks of age was $4.73, .84$ and 0.96 for ND, $\mathrm{H}$ and $\mathrm{NN}$ genotypes. In females, the corresponding figures were $4.35,1.64$ and 0.43 . Genotype wise expected response to selection for 8 week body weight is shown in Table 3. As a result of selection, body weight at 8 weeks of age was expected to improve by 51.21 vs. $24.03 ; 37.74$ vs. 15.47 and 26.26 vs. $9.65 \mathrm{~g}$; respectively for ND, $\mathrm{H}$ and NN males and females. Depending on a selective breeding, results from the present study indicate that on an average weight gain is $27 \mathrm{~g}$ and it would take approximately 5 to 6 generations of selection, which corresponds to around 3 to 4 years of selection for improving body weight at 8 week from their current population mean of $349 \mathrm{~g}$ to the desired population mean of $500 \mathrm{~g}$.

\subsection{Comparison between second generation $\left(\mathbf{G}_{\mathbf{2}}\right)$ and foundation stock $\left(\mathbf{G}_{\mathbf{0}}\right)$}

Weight gains in indigenous chicken at hatch and at 8 week of age for $\mathrm{G}_{2}$, were -1.97, -1.94, $0.44 \mathrm{~g}$ and 107.34, $175.95,150.70 \mathrm{~g}$; respectively for ND, $\mathrm{H}$ and NN genotypes (Table 4). It was observed that all genotypes came to sexual maturity as 8 to 19 days earlier in the second generation $\left(G_{2}\right)$ than that of the foundation stock $\left(G_{0}\right)$. Egg production increased as 3 to 14 numbers in the second generation $\left(\mathrm{G}_{2}\right)$ than that of the foundation stock $\left(\mathrm{G}_{0}\right)$. Egg weight decreased in ND $(-0.48 \mathrm{~g})$ and $\mathrm{NN}(-0.3 .24 \mathrm{~g})$ but increased in $\mathrm{H}(1.47 \mathrm{~g})$. Body weight increased by 202.91, 337.36 and $72.82 \mathrm{~g}$ at 40 week of age; respectively for ND, H and NN genotypes. Singh and Singh (1989) reported that as a result of selection egg production is expected to improve by 6.76 eggs with minimum decrease in age at first egg (1.46 days) and marginal decline in egg weight $(0.127 \mathrm{~g})$ per generation.

Table 1. Effect of genotype on carcass characteristics.

\begin{tabular}{lllll}
\hline Parameter & \multicolumn{3}{c}{ Genotype } & P-value \\
\cline { 2 - 5 } & $\begin{array}{l}\text { ND } \\
\text { Mean } \pm \text { SD }\end{array}$ & $\begin{array}{l}\text { H } \\
\text { Mean } \pm \text { SD }\end{array}$ & $\begin{array}{l}\text { NN } \\
\text { Mean } \pm \text { SD }\end{array}$ & \\
\hline Live weight $(\mathrm{g})$ & $756.50^{\mathrm{b}} \pm 157.62$ & $798.50^{\mathrm{a}} \pm 198.38$ & $763.16^{\mathrm{b}} \pm 174.72$ & $\mathrm{P}<0.05$ \\
Dressing \% & $66.92^{\mathrm{a}} \pm 1.77$ & $65.40^{\mathrm{b}} \pm 2.50$ & $67.29^{\mathrm{a}} \pm 1.79$ & $\mathrm{P}<0.001$ \\
\hline
\end{tabular}

${ }^{\mathrm{ab}}$ Means with dissimilar superscripts in a row are significantly different $(\mathrm{p}<0.05)$

Table 2. Effect of slaughter age on carcass characteristics.

\begin{tabular}{lllll}
\hline Parameter & \multicolumn{3}{c}{ Slaughter age } & P-value \\
\cline { 2 - 4 } & $\begin{array}{l}\mathbf{8} \mathbf{w k} \\
\text { Mean } \pm \text { SD }\end{array}$ & $\begin{array}{l}\mathbf{1 0} \mathbf{w k} \\
\mathbf{M e a n} \pm \text { SD }\end{array}$ & $\begin{array}{l}\mathbf{1 2} \mathbf{w k} \\
\text { Mean } \pm \text { SD }\end{array}$ & \\
\hline Live weight $(\mathrm{g})$ & $586.66^{\mathrm{c}} \pm 39.45$ & $741.94^{\mathrm{b}} \pm 51.70$ & $989.38^{\mathrm{a}} \pm 64.85$ & $\mathrm{P}<0.001$ \\
Dressing yield $(\%)$ & $66.90^{\mathrm{b}} \pm 1.50$ & $64.53^{\mathrm{c}} \pm 1.78$ & $68.18^{\mathrm{a}} \pm 1.43$ & $\mathrm{P}<0.001$ \\
\hline
\end{tabular}

\footnotetext{
${ }^{a b c}$ Means with dissimilar superscripts in a row are significantly different $(p<0.05)$
} 
Table 3. Expected response to selection for 8 weeks body weight $(\mathrm{g})$ in second generation $\left(\mathrm{G}_{2}\right)$.

\begin{tabular}{|c|c|c|c|c|c|c|c|c|c|c|}
\hline \multirow[t]{2}{*}{ 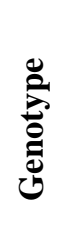 } & \multirow[t]{2}{*}{ ڤั } & \multirow{2}{*}{ 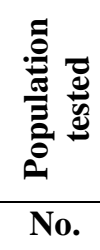 } & \multicolumn{3}{|c|}{ 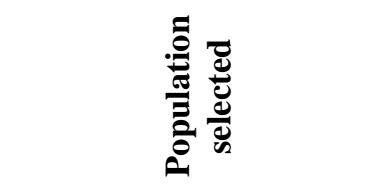 } & \multirow{2}{*}{ 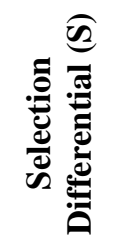 } & \multirow[t]{2}{*}{ 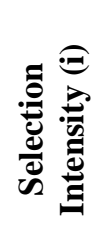 } & \multirow{2}{*}{ 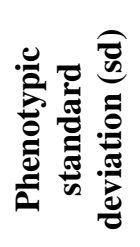 } & \multirow{2}{*}{ 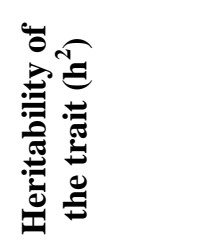 } & \multirow{2}{*}{ 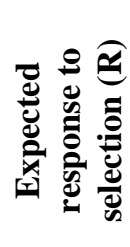 } \\
\hline & & & Aver. & No. & Aver. & & & & & \\
\hline \multirow[t]{2}{*}{ ND } & M & 420 & 497.32 & 85 & 599.94 & 102.63 & 4.73 & 21.68 & $0.499 \pm 0.030$ & 51.21 \\
\hline & $\mathrm{F}$ & 479 & 401.77 & 230 & 449.94 & 48.18 & 4.35 & 11.07 & & 24.03 \\
\hline \multirow[t]{2}{*}{$\mathrm{H}$} & M & 182 & 582.46 & 45 & 659.66 & 77.20 & 0.84 & 92.16 & $0.489 \pm 0.027$ & 37.74 \\
\hline & $\mathrm{F}$ & 186 & 519.78 & 115 & 551.43 & 31.65 & 1.64 & 19.30 & & 15.47 \\
\hline \multirow[t]{2}{*}{ NN } & $\mathrm{M}$ & 157 & 536.61 & 45 & 591.56 & 54.94 & 0.96 & 57.25 & $0.478 \pm 0.034$ & 26.26 \\
\hline & $\mathrm{F}$ & 168 & 428.07 & 115 & 448.27 & 20.19 & 0.43 & 46.62 & & 9.65 \\
\hline
\end{tabular}

Table 4. Comparison between second generation $\left(G_{2}\right)$ and foundation stock $\left(G_{0}\right)$.

\begin{tabular}{cllll}
\hline \multirow{2}{*}{ Parameter } & Generation & \multicolumn{3}{c}{ Genotype } \\
\cline { 3 - 5 } & & ND & H & NN \\
\hline Chick wt $(\mathrm{g})$ & $\mathrm{G}_{0}$ & 27.74 & 28.00 & 24.96 \\
& $\mathrm{G}_{2}$ & 25.77 & 26.06 & 25.40 \\
& gain/change & -1.97 & -1.94 & 0.44 \\
8 wk wt (g) & $\mathrm{G}_{0}$ & 342.20 & 375.17 & 331.64 \\
& $\mathrm{G}_{2}$ & 449.54 & 551.12 & 482.34 \\
& gain/change & 107.34 & 175.95 & 150.70 \\
ASM (days) & $\mathrm{G}_{0}$ & 160.73 & 166.06 & 160.04 \\
& $\mathrm{G}_{2}$ & 150.27 & 158.27 & 141.29 \\
& & -10.465 & -7.79 & -18.75 \\
40 wk wt (g) & $\mathrm{G}_{0}$ & 1177.35 & 1377.53 & 1170.47 \\
& $\mathrm{G}_{2}$ & 1380.26 & 1714.89 & 1243.29 \\
Egg & gain/change & 202.91 & 337.36 & 72.82 \\
(no.) & $\mathrm{G}_{0}$ (24-40 wks) & 60.04 & 56.19 & 55.28 \\
& $\mathrm{G}_{2}(24-40$ wks) & 74.02 & 58.33 & 66.86 \\
Egg wt (g) & gain/change & 13.98 & 2.14 & 11.58 \\
& $\mathrm{G}_{0}$ (at 38-40 wks) & 42.26 & 41.14 & 41.61 \\
& $\mathrm{G}_{2}$ (at 38-40 wks) & 41.78 & 42.61 & 38.37 \\
& gain/change & -0.48 & 1.47 & -3.24 \\
\hline
\end{tabular}

\section{Conclusions}

The results revealed that among the indigenous genotypes $\mathrm{H}$ genotype was superior in terms of body weight, and NN genotype was for dressing percentage. NN genotype was also found reaching maturity earlier but attaining a lighter mature weight. In each generation slight response was obtained for selection. These findings give an impetus for continuing the pure breeding research for more generations.

\section{Conflict of interest}

None to declare.

\section{References}

Bhuiyan AKFH, MSA Bhuiyan and GK Deb, 2005. Indigenous chicken genetic resources in Bangladesh: Current status and future outlook. Animal Genetic Resources Information's Bulletin, 36: 73-84.

Falconer DS, 1981. Selection response and its prediction, Introduction to Quantitative Genetics, Second Edition, pp. 171-177.

Faruque S, AKFH Bhuiyan, MM Rahman and MN Islam, 2011. Breeding for the improvement of indigenous chickens of Bangladeh. Proceedings of the Annual Research Review Workshop, 28-29 June 2011, Bangladesh Livestock Research Instiute, Savar, Dhaka, pp. 51-52.

Hazary RC, DC Johari, MC Kataria and SC Mohapara, 1990. Evaluation of response to selection for egg mass in a Rhode Island Red flock.2. Correlated response. Indian J. Poult. Sci., 26: 71-76. 
Iqbal S, ZA Pampori and D Hasin, 2009. Carcass and egg characteristics of indigenous chicken of Kashmir (Kashmir favorella). Indian Journal of Animal Research, 43: 194-196.

Kotula AW, JE Thomson and JA Kinner, 1960. Weight increase during chilling of broilers as influenced by methods of opening the abdominal cavity during evisceration. Poult. Sci., 39: 26-27.

Pandey NK and G Shyamsunder, 1990. Carcass characteristics, meat yield and physicochemical properties of meat from white leghorn cockerels. Indian Journal of Poultry Science, 25: 249-252.

Prasad VLK, 2000. Consultency Report on Poultry Breeding. Bangladesh Livestock Research Institute, Savar, Dhaka-1341.

Singh PK, VK Khatta, RS Thakur, S Dey and ML Sangwan, 2003. Effects of phytase supplementation on the performance of broiler chickens fed maize and wheat based diets with different levels of non-phytate phosphorus. Asian Australasian Journal of Animal Sciences, 16: 1642-1649.

SPSS (Statistical Procedures for Social Sciences), 1998. SPSS 11.5 for windows. 